\title{
PERAN GURU DALAM MENINGKATKAN MOTIVASI BELAJAR SISWA SELAMA PANDEMI COVID-19
}

\author{
RATNAWATI DAN MIR'ATUL HASANAH \\ MTs Negeri Luwu Utara \\ Email : ratnabintang2@gmail.com
}

\begin{abstract}
ABSTRAK
Artikel ini akan mendiskusikan bagaimana peran guru dalam meningkatkan motivasi belajar siswa selama pandemi Covid-19. Metode yang digunakan dalam artikel ini adalah metode deskriptif yang mencoba untuk merepresentasikan data yang berhubungan dengan bagaimana pentingnya peran guru dalam meningkatkan motivasi belajar siswa selama pandemi Covid-19 berlangsung. Berdasarkan data yang ditemukan bahwa guru merupakan salah satu kunci keberhasilan dalam pendidikan setiap siswa. Mereka adalah sosok yang berinteraksi langsung dan mengamati setiap perilaku belajar siswa. Oleh karena itu, keberhasilan akademik yang sangat terpengaruh oleh motivasi belajar siswa, khususnya selama pandemi sekarang ini, akan selalu bisa terjaga bahkan meningkat jikalau guru mampu mengelola kelas daringnya sebaik dan semenarik mungkin sehingga siswa selalu memiliki alasan untuk hadir dan berpartisipasi dalam kelas tersebut. Guru sebagai pengelola kelas dapat melakukan beberapa upaya yang dapat meningkatkan motivasi belajar siswa selama pandemi saat ini, antara lain: 1) memikat minat siswa dengan kelas daring yang dikelola guru dengan memanfaatkan alat bantu dan fasilitas seefisien mungkin; 2) membuat kelas lebih bersifat sosial dengan tetap memperhatikan dan memberikan ruang bagi siswa untuk berinteraksi dengan teman sekelasnya; 3) memberikan kuis, penilaian dan tantangan yang memicu sifat kompetitif siswa; dan 4) membiarkan siswa berpartisipasi sehingga mereka merasa dibutuhkan dan terdengar aspirasinya dalam kelas daring.
\end{abstract}

Kata Kunci: Guru, Motivasi Belajar, Kelas Daring, Covid-19.

ABSTRACT
This article will discuss how the teacher's role in increasing student learning motivation during the Covid-19 pandemic. The method used in this article is a descriptive method that attempts to represent data related to how important the role of teachers is in increasing student learning motivation during the Covid-19 pandemic. Based on the data found that the teacher is one of the keys to success in the education of every student. They are people who interact directly and observe students' learning behavior. Therefore, academic success which is greatly influenced by student learning motivation, especially during the current pandemic, will always be maintained and even increase if teachers are able to manage their online classes as well and as attractive as possible so that students always have a reason to attend and participate in the class. Teachers as class managers can make several efforts that can increase student motivation during the current pandemic, including: 1) attract students' interest with online classes that are managed by teachers by using tools and facilities as efficiently as possible; 2) make the class more social by paying attention and providing space for students to interact with their classmates; 3) providing quizzes, assessments and challenges that trigger students' competitive nature; and 4) let students participate so that they feel needed and heard by their aspirations in online classes.

Keywords: Teacher, Learning Motivation, Online Class, Covid-19.

\section{PENDAHULUAN}

Penyebaran virus Corona (Covid-19) telah mempengaruhi seluruh aspek kehidupan selama setahun belakangan ini. Seperti halnya memberikan pengaruh pada setiap sektor kehidupan, pandemi Covid-19 ini juga sangat berdampak pada dunia pendidikan dalam berbagai cara. Dalam menyikapi adanya pandemi Covid-19 ini, langkah yang diambil oleh pemerintah Indonesia saat ini yakni dengan mengurangi penyebarannya dengan 
memperkenalkan peraturan pembatasan kontak sosial (social distancing)yang merupakan tujuan utama yang ingin direalisasikan sebagai solusi mengatasi pandemi ini.Oleh karena itu, pembatasan sosial juga sangat berdampak pada berjalannya proses pendidikan di Indonesia di semua jenjang pendidikan.

Banyak negara yang sudah menangguhkan pembelajaran dan ujian tatap muka dengan tujuan menempatkan pembatasan guna mencegah terjadinya penyebaran virus. Hal ini pun juga menjadi pertimbangan bagi pemerintah Indonesia. Pemerintah Indonesia melalui Kementerian Pendidikan dan Kebudayaan (Kemendikbud) menerbitkan Surat Edaran Nomor 4 Tahun 2020 mengenai pembelajaran dari rumah("Mendikbud Terbitkan SE Tentang Pelaksanaan Pendidikan Dalam Masa Darurat Covid-19," 2020).Adanya kebijakan Belajar Dari Rumah (BDR) merupakan salah satu langkah yangcoba diambil oleh pemerintah dalam hal menerapkan serta mencegah terjadinya penyebaran dan pembentukan klasterbaru di lingkup sekolah ataupun kampus. Dengan adanya kebijakan ini menuntut adanya perubahan pola pembelajaran yang semula berupa kelas tradisional dengan tatap muka di sekolah kemudian beralih menjadi sekolah daring dengan menggunakan berbagai fasilitas dan teknologi dalam menjalankan proses pembelajaran.

Kebijakan pemerintah ini tentunya memberikan dampak positif bagi berlangsungnya proses pembelajaran di tengah-tengah keharusan untuk menjaga jarak dan mengurangi intensitas pertemuan dengan orang lain. Namun, tidak dapat disangkal bahwa hal ini juga memberikan efek negatifkhususnya bagi pelajar. Sebuah penelitian menunjukkan bahwa ketika siswa tidak berada di sekolah, contohnya, ketika mereka berlibur atau belajar di rumah, mereka secara fisik kurang aktif dan menghabiskan hampir seluruh waktu mereka untuk menggunakan handphone. Oleh karena itu, mereka bisa sangat merasa jenuh, bahkan sampai stress baik itu ringan ataupun berat(Brazendale dkk., 2017). Selain itu, penggunaan internet dalam proses pembelajaran merupakan salah satu penyebab terjadinya perubahan psikis dalam perilaku belajar siswa. Hal ini sebagaimana diungkapkan oleh sebuah penelitian bahwa terdapat hubungan negatif yang tercipta antara kecanduan internet dengan motivasi belajar. Penelitian ini menegaskan bahwa siswa yang kecanduan internet susah untuk mengatur waktu belajar mereka secara produktif dan lebih cemas terhadap tes-tes yang akan datang. Hal ini dikarenakan mereka merasa kurang siap. Melalui penelitian ini Profesor Phil Reed dari Swansea University menegaskan bahwa: "Siswa dengan tingkat kecanduan internet yang tinggi sangat berisiko memiliki motivasi yang lebih rendah untuk belajar, dan karenanya, menurunkan kinerja akademis mereka"(Truzoli, Viganò, Galmozzi, \& Reed, 2020).

Selama pandemi Covid-19 ini masih berlangsung dan belum mereda, proses pembelajaran mau tidak mau masih akan tetap diadakan di rumah dengan berbagai syarat yang telah ditentukan oleh pemerintah. Oleh karena itu, pembelajaran dari rumah harusnya menjadi solusi yang terbaik untuk saat ini. Namun mengingat fakta bahwa BDR ini ternyata juga memberi efek negatif pada siswa dimana proses pembelajaran yang dilakukan di rumah mengakibatkan siswa kecanduan internet sehingga kesulitan untuk mengatur waktu mereka dengan bijaksana dan hal ini menjurus pada menurunnya motivasi belajar yang pada akhirnya menghilangkan kepercayaan diriterhadap kemampuan yang mereka milikisehingga berdampak pada menurunnya kemampuan dan keberhasilan akademiksiswa.

Penurunan kemampuan akademik siswa merupakan hal yang harus dihindari. Oleh karena itu, peran guru sebagai tenaga professional di bidang pendidikan yang berperan dalam mengelola interaksi belajar mengajar diharap dapat mengatasi problemaini(Sudjana, 2004). Guru memiliki tugas utama untuk menyampaikan serta menyajikan bahan pembelajaran yang bisa diterima oleh siswa dengan penuh gairah dan senang(Davies, 1991). Dalam konteks ini, peran guru sebagai motivator(A.M, 2008) sangat dibutuhkan untuk meningkatkan motivasi dan gairah belajar siswa sehingga penurunan kemampuan akademik mereka bisa terhindari. 


\section{METODE PENELITIAN}

Artikel ini menggunakan metode studi literatur untuk menganalisis bagaimana peran guru dalam meningkatkan motivasi belajar siswa selama pandemic Covid-19. Pada penelitian ini, data-data dikumpulkan melalui teknik dokumentasi terhadap data-data yang berkaitan dengan permasalahan motivasi belajar siswa selama pandemic, baik yang didapat melalui artikel-artikel terkini maupun melalui buku-buku. Data-data ini kemudian dianalisis menggunakan teknik data kualitatif dengan penyajian data secara deskriptif dengan tujuan agar data-data tersebut bisa dipaparkan secara mendalam, terperinci dan mendetail.

\section{HASIL DAN PEMBAHASAN}

\section{A. Motivasi Belajar}

Kehadiran motivasi belajar selama proses pembelajaran dari rumah sangatlah penting. Hadirnya motivasi siswa untuk belajar bisa menjadi magnet tersendiri bagi keberhasilan tujuan pendidikan dan tercapainya kemampuan akademik siswa yang seharusnya bisa terlaksana sebagaimana terlaksana selama masa belajar tatap muka.

Kata motif berasal dari bahasa Latin "movers", yang berarti menggerakkan (Fudyartanto, 2002). Sama dengan yang dikemukakan Winkel (Winkel, 1983), motif adalah daya penggerak dari dalam dan di dalam subyek untuk melakukan aktivitasaktivitas tertentu demi mencapai suatu tujuan.Kata motivasi lalu diartikan sebagai usaha menggerakkan. Menurut A. W. Bernard seperti yang dikutip oleh Fudyartanto(Fudyartanto, 2002), motivasi menunjukkan semua fenomena yang dilibatkan dalam stimulasi (perangsangan) tindakan ke arah tujuan - tujuan tertentu dimana sebelumnya kecil atau tidak ada gerakan ke arah tujuan - tujuan itu. Jadi motivasi adalahusaha memperbesar atau mengadakan gerakan mencapai tujuan tertentu.

Mc. Donald(A.M, 2008) mengatakan bahwamotivasi adalah perubahan energi dalamdiri seseorang yang ditandai denganmunculnya "feeling" dan didahului dengantanggapan terhadap adanya tujuan. Padaintinya bahwa motivasi merupakan kondisipsikologis yang mendorong seseoranguntuk melakukan sesuatu. Dalam kegiatanbelajar, motivasi sangat diperlukan, sebabseseorang yang tidak mempunyai motivasidalam belajar, tidak akan mungkinmelakukan aktivitas belajar.Parsons dkk (Parsons \& Hinson, 2000) mendefinisikan motivasi sebagai komponen atau faktor penting dalam proses pembelajaran. Belajar dan motivasi memiliki kepentingan yang sama untuk mencapai sesuatu. Belajar membuat kita memperoleh pengetahuan dan keterampilan baru dan motivasi mendorong kita untuk melalui proses pembelajaran.

Adapun berkaitan dengan motivasi belajar, menurut Winkel (Winkel, 1983), motivasi belajar adalah keseluruhan dayapenggerak di dalam diri siswa yang menimbulkan kegiatan belajar, yangmenjamin kelangsungan dari kegiatan belajar dan yang memberikan arah padakegiatan belajar itu; maka tujuan yang dikehendaki oleh siswa tercapai.Motivasi belajar merupakan faktor psikis, yang bersifat nonintelektual.Peranannya yang khas ialah dalam hal gairah/semangat belajar; siswa yangbermotivasi kuat akan mempunyai banyak energi untuk berpartisipasi dalam kegiatanbelajar. Jadi, dapat dikatakan bahwa motivasi adalah usaha untukmeningkatkan kegiatan dalam mencapai sesuatu tujuan. Motivasi itu berlaku untuk semua kegiatan termasuk kegiatan belajar. Jika dikatakan motivasi belajar, maksudnya adalah mendorong atau memberi semangat kepada individu yang melakukan kegiatan belajar, agar lebih giat belajar supaya prestasinya meningkat menjadi lebih baik (Fudyartanto, 2002).

Lebih jauh lagi Sanjaya (Sanjaya, 2008)menegaskan bahwa hadirnya motivasi selama proses pembelajaran merupakan salah satu aspek dinamis yang paling penting. Fakta menunjukkan bahwa kurangnya motivasi siswa dalam belajar sangat memberikan pengaruh pada prestasinya di sekolah, hal ini dikarenakan ia tidak memiliki motivasi untuk belajar dan berusaha untuk mengerahkan segala apa yang ia miliki untuk mencapai tujuannnya, bukan dikarenakan ia memiliki kemampuan yang kurang. Oleh karena hal 
inilah mengapa kehadiran motivasi belajar bagi setiap siswa sangat penting dan mutlak adanya, khususnya pada masa pandemi saat ini yang dimana sarana dan lingkungan bisa sangat membantu dalam menurunkan bahkan menghilangkan motivasi belajar siswa.

Berkaitan dengan hal ini, motivasi pada dasarnya terbagi dua, yakni motivasi intrinsik dan ekstrinsik. Konsep motivasi ini merupakan konsep yang paling kuat dari seluruh konsep umum mengenai motivasi, khususnya berkaitan dengan motivasi belajar siswa. Edward Deci(Deci, 2012) memaparkan bahwa segala aktivitas yang termotivasi secara intrinsikadalah aktivitas yang tidak mengharapkan imbalan apapun selain aktivitas itu sendiri. Individu yang terdorong oleh motivasi intrinsiknya ketika melakukan suatu aktivitas, tujuannya adalah untuk kepentingan dirinya sendiri bukan karena ada dorongan ataupun paksaan dari luar dirinya. Siswa yang termotivasi secara intrinsikterlibat dalam proses pembelajaran karena dimaksudkan untuk mewujudkan konsekuensi-konsekuensi tertentu yang memberikan imbalan secara internal, yaitu perasaan kompeten dan bangga dalam menentukan nasib sendiri.

Pendapat Deci ini didukung oleh apa yang diutarakan oleh Arnold mengenai motivasi intrinsik. Menurutnya, motivasi intrinsik mengacu pada belajar itu sendiri, di mana imbalannya adalah belajar itu sendiri (Arnold, 1999). Ini berarti siswa secara sukarela (tidak wajib) mencoba mempelajari apa yang menurut mereka layak atau penting bagi mereka. Ketika siswa memiliki motivasi intrinsik, mereka memiliki keinginan internal untuk belajar dan mereka tidak memiliki kebutuhan untuk imbalan eksternal. Tidak ada dampak negatif dalam memiliki motivasi intrinsik. Selain itu, motivasi intrinsik mendorong siswa untuk belajar tanpa mengharapkan imbalan, karena kebutuhan adalah bawaan atau berasal dari dalam atau tergantung pada keinginan mereka sendiri.

Di lain pihak, motivasi ekstrinsik hadir karena adanya ransangan yang berasal dari luar(Deci, 2012). Ransangan-ransangan ini bisa berupa materi, nilai ujian, hadiah, bahkan pujian dari orang lain. Siswa yang mengerjakan tugas karena ingin menghindari hukuman dari gurunya pun bisa dikatakan termotivasi secara eksternal.Motivasi ini menekankan kebutuhan eksternal untuk membujuk siswa untuk mengambil bagian dalam kegiatan belajar (Arnold, 1999), seperti pekerjaan rumah, kelas, atau melakukan sesuatu untuk menyenangkan guru.Dikarenakan motivasi ekstrinsik didasarkan pada imbalan eksternal seperti penghargaan dan hukuman, motivasi ini dapat membawa dampak negatif bagi siswa, karena dengan motivasi ekstrinsik, siswa tidak belajar dengan niat atau kemauan yang kuat tetapi mereka mempelajarinya karena mereka didorong oleh minat pada hadiah atau hukuman. Ketika seorang siswa berhasil karena dia dijanjikan hadiah atau karena dia menginginkan hadiah, dia akan sangat termotivasi untuk datang ke kelas dan belajar dan mencapai tujuan yang ditentukan untuknya. Tetapi ketika hadiah ini diambil, atau kadangkadang bahkan jika mereka tidak melihat hukuman apa pun, siswa tidak akan tertarik untuk datang ke kelas dan belajar lebih giat lagi.

Kehadiran motivasi belajar sangat penting dalam meningkatkan proses dan keberhasilan pembelajaran(Sugihartono, Fathiyah, Harahap, Setiawati, \& Nurhayati, 2007), khususnya dalam keadaan seperti saat ini dimana motivasi sangat dibutuhkan siswa untuk menjalani proses pembelajaran mereka dari rumah yang notabenenya membuat mereka jenuh dan kurang termotivasi serta hilang semangat untuk berkompetisi dan meraih prestasi belajar. Motivasi yang tinggi bisa merangsang siswa untuk meningkatkan aktivitas belajar mereka di rumah dan hal ini akan tercermin dari perilaku-perilaku mereka selama mengikuti pembelajaran dari rumah.

Hubungan antara motivasi belajar dengan aktivitas belajar siswa selalu berjalan beriringan. Sugihartono(Sugihartono dkk., 2007) menjelaskan bahwa hubungan ini tercermin pada siswa yang memiliki motivasi belajar yang tinggi akan berdampak pada kualitas keterlibatan siswa yang tinggi pada proses pembelajarannya. Adanya motivasi belajar yang dimiliki siswa tersebut akan memunculkan perasaan dan keterlibatan afektif yang tinggi dalam belajar. Oleh karena itu, keberhasilan belajar seorang siswa dalam 
proses pembelajaran sangat dipengaruhi oleh hadirnya motivasi selama proses tersebut. Motivasi ini bisa saja berupa motivasi intrinsikyang berorientasi pada dirinya sendiri ataupun motivasi ekstrinsik yang diransang oleh faktor-faktor eksternal di luar dirinya.

\section{B. Peran Guru Sebagai Motivator Selama Proses Pembelajaran Daring}

Guru merupakan salah satu faktor terpenting dalam menentukan mutu pendidikan. Guru dianggap sebagai komponen utama yang memengaruhi proses pendidikan. Hal ini dianggap wajar, karena guru merupakan komponen utama dalam proses pendidikan yang berinteraksi secara langsung dengan siswa sebagai subjek dan objek belajar(Sanjaya, 2011).Di tangan gurulah tercipta siswa yang memiliki kemampuan yang berkualitas, baik itu secara akademis, keahlian, kematangan emosional, moral serta spiritual(Kunandar, 2007). Dengan demikian, dengan campur tangan yang baik dari guru, siswa diharapkan mampu menghadapi tantangan dunia pendidikan dengan baik selama masa pandemi Covid19 ini.

Di masa pandemi saat ini, tantangan dan persoalan yang dihadapi di dunia pendidikan menjadi semakin rumit. Kondisi pandemi Covid-19 saat ini telah mengubah sistem danproses belajar. Dalam kondisi normal, pembelajaran umumnya dilakukan secara langsungtatap muka antara guru dan siswa. Sistem pembelajaran seperti itu membuatnya lebih mudahbagi guru untuk secara langsung mengontrol hasil belajar siswa. Melalui pembelajaran tatap mukajuga memudahkan guru untuk memberikan umpan balik dan membantu siswa dalam mengatasi masalah belajar mereka.

Keberlangsungan kondisi pandemi Covid-19 ini memaksa pemerintah dan masyarakat untuk mengadopsi perilaku hidup normal baru yang dalam setiap aktivitasnya menerapkan protokol kesehatan (Rahardjo \& Pertiwi, 2020).Diberlakukannya sistem BDR menggantikan pola belajar klasik yang dilakukan di sekolah secara tatap muka ternyata selain menjadi solusi bagi keberlangsungan proses belajar mengajar dalam rangka pembatasan dan pemutusan rantai penyebaran Covid-19, ternyata langkah ini juga tidak bisa dipungkiri memberikan efek negatif terhadap perilaku belajar siswa. Penurunan bahkan hilangnya motivasi belajar siswa selama proses BDR ini memberikan pengaruh yang sangat besar terhadap kemampuan serta hasil akademik siswa(Rahardjo \& Pertiwi, 2020).Oleh karena itu, kehadiran guru sebagai seorang motivator sangat dibutuhkan untuk meningkatkan motivasi belajar siswa saat ini.

Mengajar bukan saja tentang menyampaikan materi pelajaran, akan tetapi bagaimana membimbing serta mengarahkan perilaku siswa ke arah yang diharapkan(Sanjaya, 2011). Oleh karena itu, selama proses pembelajaran guru diharapkan menghadirkan kegiatan-kegiatan yang bisa mengembangkan kemampuan siswa, melatih keterampilan intelektual serta motorik mereka sehingga siswa mampu menghadapi dan melalui kondisipandemi saat ini dengan baik. Dengan kegiatan-kegiatan yang diberikan guru, siswa bisa memiliki motivasi untuk terus belajar dan mencari informasi di mana pun dengan memanfaatkan situasi dan kondisi belajar yang saat ini yang sangat bergantung pada internet.

Peran guru sangat penting dalam rangka menumbuhkan motivasi belajar selama proses pembelajaran. Hal ini ditegaskan oleh Hamalik dalam (Sanjaya, 2008)bahwa salah satu faktor yang mempengaruhi munculnya motivasi, baik itu motivasi intrinsik ataupun motivasi ekstrinsik adalah sikap guru terhadap kelas, dalam artian bahwa guru memiliki tugas untuk selalu merangsang siswa bertindak ke arah tujuan yang jelas dan bermakna akan menumbuhkan motivasi belajar bagi siswa.Terlebih lagi bahwa siswa menunjukkan ketertarikan dan lebih termotivasi terhadap guru yang mereka sukai dibandingkan dengan guru yang kurang mereka sukai(Sanjaya, 2008). Oleh karena itu, seorang guru harus mampu dan memiliki kecakapan menciptakan kelas yang mampu menarik minat dan meningkatkan motivasi belajar siswa-siswanya. 
Berkaitan dengan hal itu, terdapat beberapa hal yang dapat dilakukan oleh guru untuk meningkatkan motivasi belajar siswa selama pandemi, antara lain:

1. Memikat Minat Siswa dengan Kelas Daring Guru

Ketika seorang guru membuat sebuah kelas daring, salah satu cara untuk memotivasi siswa dan membuat mereka tertarik dengan kelas tersebut adalah dengan membuat kelas tersebut semenarik mungkin. Sebuah kelas yang memiliki berbagai macam elemen multimedia biasanya lebih interaktif dibandingkan dengan kelas yang menoton, menjenuhkan dan membosankan secara visual. Jika seorang guru mampu membuat kelas daringnya unik dan menarik perhatian siswanya, ia memberikan alasan tambahan bagi siswanya untuk menghadiri kelas tersebut.

Penggunaan alat bantu memungkinkan guru untuk memanfaatkan respon emosional siswa daringnya. Ketika guru berhasil melakukan hal tersebut, ia menarik perhatian mereka dan membuat mereka menerima lebih banyak informasi dan belajar lebih baik serta lebih cepat. Seorang guru dapat menggunakan gambar dan video yang memberikan berbagai macam tanggapan atau membuat beberapa contoh yang berkaitan dengan topik yang menarik minat siswa daripada hanya selalu memaparkan konsep abstrak mengenai suatu materi.

Sebuah gambar lebih berarti dari seribu kata. Jika guru mampu menghadirkan gambar yang tepat dalam situasi belajar, akan terjadi hal yang menakjubkan. Bukan hanya memulai proses belajar dengan cara meransang modalitas visual siswa, akan tetapi alat bantu juga secara harfiah menyalakan jalur saraf(Singer-Nourie, 2010),dan semua hal ini akan membuat siswa lebih tertarik terhadap kelas tersebut. Namun, perlu diperhatikan bahwa penggunaan alat bantu secara berlebihan juga tidak baik karena hal ini akan mengalihkan siswa dari inti materi yang ingin disampaikan.

Musik juga bisa dijadikan pilihan lain untuk menarik minat siswa. Musik bisa digunakan oleh seorang guru untuk menata suasana hati, mengubah keadaan mental siswa dan mendukung lingkungan belajar siswa. Musik membantu siswa belajar lebih baik dan mengingat lebih banyak materi pembelajarannya.Musik memperkuat, meremajakan dan meransang proses belajar siswa, baik itu secara sadar maupun tidak sadar(Singer-Nourie, 2010).Musik dapat membantu siswa merasa belajar dalam keadaan yang lebih optimal.

2. Membuat Kelas Lebih Bersifat Sosial

Menjadikan kelas daring seinteraktif mungkin merupakan salah satu cara yang dapat memotivasi siswa untuk berpartisipasi di sebuah kelas daring. Siswa biasanya terbiasa dengan fitur media sosial seperti berkomentar dan berbagi konten daring. Memiliki fitur seperti ini sebagai bagian dari proses pembelajaran daring dapat meningkatkan partisipasi dan keterlibatan siswa. Seorang guru juga harus membuat siswanya berkomunikasi dan berinteraksi satu sama lain.

Ketika siswa memiliki interaksi sosial positif dengan temannya maupun dengan gurunya, mereka akan menjadi lebih terikat dengan pelajarannya. Interaksi positif dengan teman sejawat serta guru mereka dalam sebuah kelas merupakan hal yang penting(Palmer, 2007).Interaksi sosial bisa muncul ketika siswa bekerja dalam bentuk kelompok, memiliki kelompok diskusi, proyek dan presentasi kelompok. Para siswa perlu dipersiapkan dengan baik untuk memberikan mereka keterampilan dalam mengelola kelompok dan membuat kelompok tersebut beroperasi dengan efektif.

Kerja sama antar siswa bisa memberikan efek positif terhadap pembelajaran. Dalam sebuah kelompok, setidaknya masing-masing memiliki empat kompetensi: menghasilkan dan menyempurnakan ide, mengatur dan mengintegrasikan tugas, mempertahankan semangat kelompok, serta mampu mengelola batasan-batasan yang dimiliki kelompok tersebut. "kelompok yang cerdas" dibentuk dengan memiliki seluruh anggota kelompok yang memperhatikan kompetensi apa yang dibutuhkan kelompok tersebut untuk menjadi efektif. Sebagai contoh, perbedaan budaya harus 
dianggap sebagai pemersatu pemahaman, penyeimbang dalam bekerja maupun dalam hidup (Friedman, 2009). Oleh karena itu, membangun dan menciptakan sebuah kelompok yang memiliki interaksi dan komunikasi yang baikantar anggota kelompok sangat diperlukan.

Bahkan untuk sebuah kelas daring yang lebih berfokus pada pembelajaran individualistik, guru masih dapat menggunakan forum daring dan media lain yang mendorong terciptanya diskusi kelompok dan pemecahan masalah kolektif. Memasukkan strategi sosial ini ke dalam rencana pembelajaran daring akan menambah sentuhan humanis pada kelas daring tersebut. Ini mungkin tidak sebanyak yang akan bisa guru dapatkan dengan mengadakan pertemuan tatap muka, tetapi interaksi siswa akan memberikan beberapa bentuk motivasi dan meningkatkan pengalaman belajar mereka.

3. Memberikan Kuis, Penilaian dan Tantangan dalam Kelas Daring

Pada dasarnya manusia menyukai tantanganadalah salah satu hal kecil yang dapat memotivasi orang untuk bekerja lebih keras. Dengan memasukkan kuis, tantangan, dan penilaian ke dalam kelasdaring, guru tidak hanya mendapatkan kesempatan untuk mengevaluasi siswanya, tetapi ia juga memicu keinginan untuk berhasil pada siswa, sehingga mendorong mereka ke arah partisipasi yang lebih baik dalam kelas daringnya.

Banyak siswa yang belajar berorientasi pada nilai yang bagus. Hal ini pun memicu mereka untuk belajar lebih giat. Bagi sebagian siswa nilai yang tinggi bisa jadi motivasi yang kuat bagi mereka untuk belajar. Oleh karena itu, penilaian harus segera dilakukan dan dilaksanakan sesuai dengan kemampuan dan kondisi siswa (Sanjaya, 2011).

Guru harus mengetahui bagaimana memberikan tugas yang memotivasi siswa. Tugas tersebut harus memiliki relevansi tematik yang mana bertujuan untuk mengecek apa yang siswa telah pelajari dan apakah mereka bisa mengaplikasikannya dalam kehidupan nyata. Hal yang perlu diperhatikan pula bahwa tugas tersebut harus bersifat semudah mungkin dikerjakan bagi siswa, bahkan jika materinya itu sangat menantang. Dalam artian bahwa sebuah tugas harus memiliki instruksi, terminologi, pengaturan, serta pemilihan item yang jelas, tidak ambigu, tepat dan dirancang dengan baik(Sanjaya, 2011).Guru dapat meminta siswa untuk meringkas apa yang telah mereka pelajari sejauh ini dalam kelas, atau memasukkan masalah kehidupan nyata yang perlu mereka pecahkan di akhir setiap kelas. Ini akan meningkatkan keinginan mereka untuk memperoleh keterampilan dan pengetahuan yang dibutuhkan untuk memecahkan masalah yang diberikan dengan memperhatikan kelas daring mereka.

Banyak hal yang bisa dilakukan oleh seorang guru untuk lebih memperdalam pengetahuan siswanya mengenai materi yang dipelajari. Salah satunya adalah dengan melatih mereka untuk mengajukan pertanyaan kritis di setiap akhir kelas daring mereka. Terdapat tiga pertanyan yang dapat menjadi prasarana untuk memperkaya pengetahuan dan memperdalam pengetahuan mereka, yaitu: 1) Apa yang terjadi? 2) Apa yang saya pelajari? 3) Bagaimana cara menerapkannya?(Singer-Nourie, 2010). Dengan memberikan kesempatan bagi mereka untuk merenungkan pelajaran, guru membantu siswa membentuk pengertian konseptual yang lebih mendalam, membangun relasi yang lebih kuat dan lebih banyak lagi menekankan proses belajar.

4. Membiarkan Siswa Berpartisipasi

Cara lain untuk memberdayakan dan memotivasi siswa adalah dengan membiarkan mereka untuk menyumbangkan pengetahuan mereka tentang apa yang telah mereka pelajari selama ini. Strategi pembelajaran berbasis tugas adalah salah satu cara paling efektif untuk mendapatkan keterlibatan dalam lingkungan pembelajaran daring. Guru harus mengizinkan siswa untuk berkontribusi 
menggunakan berbagai cara dan metode. Ini dapat menginspirasi mereka dan memberi mereka bantuan yang mereka butuhkan dalam studi mereka.

Menjadikan kelas daring tetap menarik bagi siswa selama satu semester memerlukan waktu yang lama dan membutuhkan perhatian yang konsisten. Sepanjang satu semester, pastikan guru tetap dalam pedoman yang telah disepakati sebelumnya. Jaga agar siswa tetap berkontribusi dalam lingkungan belajar dan jaga agar motivasi belajar mereka tetap tinggi.

Salah satu cara agar mereka dengan senang hati mau berkontribusi dalam kelas adalah dengan menjadikan mereka sebagai mitra dalam belajar(Singer-Nourie, 2010). Terciptanya hubungan merupakan inti dari pengajaran karena hal itu merupakan sebuah kegiatan yang berbasis komunikasi(MacGrath, 2005).Empati bisa membantu untuk membangun hubungan kepercayaan (MacGrath, 2005).Elemen-elemen penting yang membangun dan menjaga hubungan secara konstruktif adalah membangun kepercayaan, guru harus berpihak pada siswa, hargai setiap individu siswa sepanjang waktu, bersikap bertanggung jawab dan membimbing mereka untuk meraih prestasi, membangun kerja sama dengan mereka, serta menunjukkan kepada mereka bahwa guru mendengar dan menerima apa yang siswa katakan.

Sebagai mitra belajar, mereka harus ikut serta dalam mengembangkan dan mendukung peraturan, tujuan kelas dan semua unsur yang berkaitan dengan berjalannya kelas tersebut.Siswa butuh untuk didorong untuk ikut serta dan berpartisipasi di setiap kelas daring yang diikutinya (Daniels, 2010). Sebuah pembelajaran harus mempertimbangkan motivasi intrinsik dan ekstrinsik siswa dan begitu pula dengan pendapat mereka dalam membentuk kelas tersebut. Materi, alat bantu serta perlengkapan yang dibutuhkan dalam proses pembelajaran harus ditentukan, diperoleh dan dimodernisasikan sehingga pembelajaran bisa menjadi lebih aktif. Keterlibatan ini membuat siswa merasa bahwa guru mereka memiliki ketertarikan khusus pada mereka(Çeliköz, 2009). Sebagai contoh adalah daripada membuat mereka membuat laporan pelajaran dengan cara yang lama dengan membuat catatan ataupun membuat laporan lisan standar, bolehkanlah mereka untuk memilih cara menyampaikan laporan dengan cara yang mereka senangi, misalnya dengan menciptakan sebuah lakon pendek dan lucu, bahkan mereka juga bisa membuat video sebagai bentuk laporan pembelajaran mereka. Dengan cara memberikan mereka berbagai pilihan, guru membiarkan siswa memegang kendali terhadap bagaimana proses pembelajarannya berlangsung. Mereka akan lebih menikmati proyek kelas dan mampu belajar lebih banyak.

Hal lain yang dapat dilakukan adalah melakukan penggambaran masa depan(Singer-Nourie, 2010). Guru dapat menggunakan penggambaran masa depan untuk menumbuhkan kegairahan siswa terhadap apa yang akan terjadi. Penggambaran masa depan juga berarti membuat ikatan. Siswa sering kali mengeluh terhadap kelas yang mereka dapati karena menurut mereka kelas tersebut pada akhirnya tidak berguna bagi kehidupan mereka nantinya di dunia nyata. Oleh karena itu, tugas seorang guru adalah bagaimana membuat ikatan itu untuk mereka. Penggambaran masa depan berguna untuk mengaitkan pelajaran di kelas dengan masa depan siswa yang mungkin saja akan mereka temui nantinya. Guru menunjukkan nilai pelajaran dalam kelasnya dan memotivasi siswa untuk sukses dalam pembelajarannya.

Penggambaran dan perencanaan masa depan akan membantu siswa untuk menghargai proses belajar mereka dan memaksimalkan waktu mereka untuk mendapatkan pembelajaran sebaik mungkin. Penggambaran ini akan menambah kepercayaan diri siswa dan mengurangi kekhawatiran siswa terhadap masa depan yang tak menentu(Dedmond, 2009). Dalam artian bahwa siswa yang memiliki visi yang jelas terhadap masa depannya akan lebih sulit menyerah ketika menghadapi kesulitan. Penggambaran ini akan lebih efektif ketika terus menerus diperbaharui, khususnya 
ketika siswa sudah mampu mengaitkan antara materi pembelajarannya dengan karir yang mereka impikan. Pada akhirnya, proses penggambaran masa depan ini akan membawa siswa pada proses belajar yang lebih produktif.

\section{KESIMPULAN}

Guru merupakan salah satu kunci keberhasilan dalam pendidikan setiap siswa. Mereka adalah sosok yang berinteraksi langsung dan mengamati setiap perilaku belajar siswa. Oleh karena itu, keberhasilan akademik yang sangat terpengaruh oleh motivasi belajar siswa, khususnya selama pandemi sekarang ini, akan selalu bisa terjaga bahkan meningkat jikalau guru mampu mengelola kelas daringnya sebaik dan semenarik mungkin sehingga siswa selalu memiliki alasan untuk hadir dan berpartisipasi dalam kelas tersebut.

Guru sebagai pengelola kelas dapat melakukan beberapa upaya yang dapat meningkatkan motivasi belajar siswa selama pandemi saat ini, antara lain: 1) memikat minat siswa dengan kelas daring yang dikelola guru dengan memanfaatkan alat bantu dan fasilitas seefisien mungkin; 2) membuat kelas lebih bersifat sosial dengan tetap memperhatikan dan memberikan ruang bagi siswa untuk berinteraksi dengan teman sekelasnya; 3) memberikan kuis, penilaian dan tantangan yang memicu sifat kompetitif siswa; dan 4) membiarkan siswa berpartisipasi sehingga mereka merasa dibutuhkan dan terdengar aspirasinya dalam kelas daring.

\section{DAFTAR PUSTAKA}

A.M, S. (2008). Interaksi \& motivasi belajar mengajar. Rajagrafindo Persada (Rajawali Pers).

Arnold, J. (Ed.). (1999). Affect in Language Learning (1st edition). Cambridge, U.K.; New York, NY: Cambridge University Press.

Brazendale, K., Beets, M. W., Weaver, R. G., Pate, R. R., Turner-McGrievy, G. M., Kaczynski, A. T., ... von Hippel, P. T. (2017). Understanding differences between summer vs. school obesogenic behaviors of children: The structured days hypothesis. International Journal of Behavioral Nutrition and Physical Activity, 14(1), 100. https://doi.org/10.1186/s12966-017-0555-2

Çeliköz, N. (2009). Basic factors that affect general academic motivation levels of candidate preschool teachers. Procedia - Social and Behavioral Sciences, 1(1), 1357-1365. https://doi.org/10.1016/j.sbspro.2009.01.240

Daniels, E. (2010). Creating Motivating Learning Environments: What We Can Learn from Researchers and Students. The English Journal, 100, 25-29. https://doi.org/10.2307/20787687

Davies, I. K. (1991). Pengelolaan Belajar. Jakarta: CV. Rajawali.

Deci, E. L. (2012). Intrinsic Motivation. Springer.

Dedmond, R. (2009). Long-Range Planning Motivates Students and Personalizes. Techniques: Connecting Education and Careers, 84(3), 20-22.

Friedman, B. (2009). Best Practices for the Implementation of Goal Setting and Peer Assessment: Curriculum and Research Design (SSRN Scholarly Paper No. ID 2513973). Rochester, NY: Social Science Research Network. Diambil dari Social Science Research Network website: https://papers.ssrn.com/abstract=2513973

Fudyartanto. (2002). Psikologi pendidikan dengan pendekatan baru. Global Pustaka Utama.

Kunandar. (2007). Guru profesional: Implementasi kurikulum tingkat satuan pendidikan (KTSP) dan persiapan menghadapi sertifikasi guru. Divisi Buku Perguruan Tinggi, RajaGrafindo Persada.

MacGrath, M. (2005). Beyond Behaviour Management: Manage or Motivate? Education Review, 19(1), 57-64.

Mendikbud Terbitkan SE tentang Pelaksanaan Pendidikan dalam Masa Darurat Covid-19. (2020, Maret 24). Diambil 26 Januari 2021, dari Kementerian Pendidikan dan 
Kebudayaan website: https://www.kemdikbud.go.id/main/blog/2020/03/mendikbudterbitkan-se-tentang-pelaksanaan-pendidikan-dalam-masa-darurat-covid19

Palmer, D. (2007). What is the best way to motivate students in science? Diambil dari https://nova.newcastle.edu.au/vital/access/\%20/manager/Repository/uon:9948?f0=sm _subject $\% 3 \mathrm{~A} \% 22$ science+education $\% 22$

Parsons, R., \& Hinson, S. L. (2000). Educational Psychology (1st edition). Australia; Belmont, CA: Wadsworth Publishing.

Rahardjo, A., \& Pertiwi, S. (2020). Learning Motivation and Students' Achievement in Learning English: JELITA, 1(2), 56-64.

Sanjaya, W. (2008). Kurikulum Dan Pembelajaran (Teori \& Praktek KTSP). Kencana.

Sanjaya, W. (2011). Strategi Pembelajaran Berorientasi Standar Proses Pendidikan (8 ed.). Jakarta: Kencana Prenada Media.

Singer-Nourie, B. D., Mark Reardon, Sarah. (2010). Quantum Teaching: Mempraktikkan Quantum Learning Di Ruang-Ruang Kelas. Kaifa.

Sudjana, N. (2004). Dasar-dasar Proses Belajar Mengajar. Bandung: Sinar Baru Algessindo.

Sugihartono, Fathiyah, K. N., Harahap, F., Setiawati, F. A., \& Nurhayati, S. R. (2007). Psikologi Pendidikan. Yogyakarta: UNY Press.

Truzoli, R., Viganò, C., Galmozzi, P. G., \& Reed, P. (2020). Problematic internet use and study motivation in higher education. Journal of Computer Assisted Learning, 36(4), 480-486. https://doi.org/10.1111/jcal.12414

Winkel, W. S. (1983). Psikologi pendidikan dan evaluasi belajar. Gramedia. 